\title{
Implementation of the Guiding Principles in the Extractive Industries in South America: Observations from the Lithium Triangle
}

\author{
Implementación de los Principios Rectores en la industria \\ extractiva en Sudamérica: observaciones desde el triángulo del
}

\begin{abstract}
The Guiding Principles are the main instrument around which business and human rights dialogue revolves. However, ten years on from their launch, it is of interest to examine their impact on state and company practice on the ground. Drawing on extensive fieldwork in the region, this article examines the impact of the Principles in the lithium extraction industry in South America. It finds that while direct adoption of them is very limited, there is significant indirect influence via the instrument's incorporation in other industry-specific or sustainability frameworks. The paper goes on to analyse the applicability of the Guiding Principles and operational steps like due diligence to indigenous rights and to situations where mining companies typically lack capacity until projects are well advanced. Some suggestions are made for increased state and
\end{abstract}

\footnotetext{
${ }^{1}$ Andy Symington is a PhD candidate in the Faculty of Law and Justice at UNSW Sydney (Australia) and an associate of the Australian Human Rights Institute. He is working in the area of business and human rights with a particular research focus on corporate engagement with Indigenous rights norms in South America's lithium industry. He also works as a human rights consultant and is an experienced and widely published freelance travel writer and journalist.
} 
community involvement in due diligence processes to make them a more robust fit to the extractive and indigenous contexts.

Keywords: business and human rights; Guiding Principles; indigenous rights; due diligence; sustainable mining

Resumen: Los Principios Rectores son el instrumento básico en torno al cual gira el debate sobre las empresas y los derechos humanos. Sin embargo, transcurridos diez años desde su lanzamiento, es interesante analizar su impacto en la práctica estatal y empresarial sobre el terreno. Basándose en un amplio trabajo de campo en la región, este artículo analiza el impacto de los Principios en la industria de extracción de litio en Sudamérica. Se constata que, si bien la adopción directa es muy limitada, existe una importante influencia indirecta debido a la inclusión del instrumento en otros marcos específicos de la industria o de la sostenibilidad. El estudio también analiza la aplicabilidad de los Principios Rectores, y las medidas operacionales como la debida diligencia, en materia de derechos de los pueblos indígenas y en situaciones en las que las empresas mineras no alcanzan la suficiente competencia hasta que los proyectos están muy avanzados. Por todo lo anterior, este estudio propone algunas sugerencias para aumentar la participación estatal y comunitaria en los procesos de debida diligencia con el fin de que se adapten mejor a los contextos mineros e indígenas.

Palabras clave: derechos humanos y empresas; Principios Rectores; derechos indígenas; debida diligencia; minería sostenible

Recibido: 9.9.2020

Aceptado: 25.3.2021

Summary

\section{Introduction}

2. The Guiding Principles in a South American context 


\section{State engagement with business and human rights}

4. Company engagement with business human rights frameworks

5. The Guiding Principles and the Nature of Mining

6. Pathways for increased state and community involvement

\section{Conclusions}

\section{Introduction}

Since they were finalised in 2011, much of the dialogue relating to corporate rights responsibilities has coalesced around the United Nations Guiding Principles on Business and Human Rights (United Nations Human Rights Council 2011a; 'GPs' or 'Guiding Principles'). Discussions in policy forums seem to attest to increasing adoption of the instrument across different regions and industries. However, business and human rights events tend to be populated by a selfselecting group of corporate representatives who represent best practice in the field; the perspectives in such conferences and forums may therefore be skewed towards the optimistic side. A decade on from the birth of the GPs, it is of interest to examine how widely and how effectively they are actually implemented on the ground and how useful a framework they seem to be for governments, for companies and - most importantly - for rights-holders. To examine this issue in detail, this paper draws on fieldwork conducted on the lithium extraction industry in South America.

South America's 'lithium triangle' is an area covering northwestern Argentina, south-western Bolivia and north-eastern Chile. In this region of the Andean altiplano, lithium is extracted from brine pumped from beneath large salt flats into evaporation tanks on the surface (for more details on the process, see Flexer, Baspineiro, and Galli 2018). Several studies of brine extraction in the region have been undertaken, focusing on environmental (e.g. Sticco 2018; Liu, 
Agusdinata, and Myint 2019), social anthropological (Babidge 2016; 2018; Göbel 2013; Gundermann and Göbel 2018), socioenvironmental (Marchegiani, Höglund Hellgren, and Gómez 2019) and political (Fornillo 2015; Nacif and Lacabana 2015; Fornillo 2019) perspectives.

However, the lithium triangle presents several key aspects that make it an interesting and appropriate object of research into the current reach of the GPs and business human rights principles more generally:

Firstly, the area includes three separate national jurisdictions Argentina, Bolivia, and Chile - with very distinct legal and governance characteristics. In federal Argentina there are also three distinct provincial jurisdictions (Catamarca, Jujuy, Salta) within the lithium triangle. Examining jurisdictional differences allows analysis of the effect of the diffusion of the GPs within different legal frameworks and governance models.

Secondly, there are present in the region companies at different stages of operation. Three have been operating for decades, allowing for analysis of how past experience has moulded corporate practice and how standards have evolved over time. Others are newer, permitting examination of how initial corporate strategies, developed in an era of business human rights dialogue, have been developed and how they are working on the ground. Most companies are still in the early stages of exploration, prospecting or planning, allowing analysis of whether and how these (often small) companies engage with business human rights issues at early junctures. The presence of companies from several distinct nations of origin also offers another factor for examination.

Thirdly, a majority of the region's population self-identifies as indigenous, ${ }^{2}$ allowing an investigation of the intersections of business

\footnotetext{
2 For relevant census data, see: INDEC, Censo 2010, 'Proporción de población indígena o descendiente de pueblos indígenas u originarios, según provincia. Año 2010',
} 
and human rights frameworks with indigenous rights and principles of self-determination.

Fourthly, there are several high-profile, public-opinion-sensitive companies (particularly producers of electric vehicles, batteries, and consumer electronics such as Apple, Samsung, Toyota, Tesla, Panasonic) in the lithium supply chain, some of them with direct stakes in extractive operations in the lithium triangle. This creates another axis of potential influence on the adoption of the GPs and/or other frameworks.

Finally, climate change is the biggest human rights issue of our time and lithium can thus be seen to have rights-enhancing potential at a global level due to the use of lithium-ion battery technology in electric vehicles and renewable energy storage, crucial elements in the necessary transition away from fossil fuels (Kazimierski 2019; Diouf and Pode 2015; Levin Sources 2017). However, true sustainability requires sustainable extraction, a principle that requires extra attention to be paid to human rights issues in the lithium triangle.

This article examines the application of the Guiding Principles in the lithium triangle, beginning with an assessment of the regional business and human rights environment (Section 2) before looking at state responses to the GPs and other frameworks (Section 3). The second part of the article, based on extensive fieldwork in the region, analyses company engagement with business and human rights principles (Section 4) and contemplates the indirect influence of the GPs via their use in other frameworks (Section 5). The article goes on to consider the sometimes-awkward fit of the GPs with indigenous rights principles and suggests pathways towards enhanced state and community involvement to strengthen due diligence and other significant business and human rights processes (Sections 6 and 7).

www.indec.gob.ar; Instituto Nacional de Estadística, www.ine.gob.bo; Gobierno de Chile, Censo 2017, www.censo2017.cl. 


\section{The Guiding Principles in a South American context}

Before addressing their implementation across the lithium triangle, an analysis of where the Guiding Principles fit within the regional business and human rights context is useful.

An obvious place to start is the Inter-American Human Rights System. Key cases of the Inter-American Court of Human Rights have examined the crossover of state and corporate responsibilities. In Velásquez Rodríguez $v$ Honduras the Court noted that lack of due diligence on a state's part to prevent or respond to a rights violation by a third party can lead to direct responsibility, ${ }^{3}$ an interpretation later echoed in the Maastricht Guidelines and other instruments (Maastricht Guidelines on Violations of Economic, Social and Cultural Rights 1997, para. 18). In Kaliña \& Lokono Peoples v Suriname the Court cited the Guiding Principles as establishing both business and state duties and found that Suriname failed to comply with its horizontal human rights obligations by not conducting an impact assessment before approving a mining project. ${ }^{4}$ The Court also referred to the GPs as establishing a standard for business in a 2017 Advisory Opinion. ${ }^{5}$

The Inter-American Commission has also extensively considered the issue. A 2019 report collates Inter-American and international materials on the subject of business and human rights, detailing the obligations of states in this sphere and the effects of these measures on companies. It refers to the GPs extensively, and describes them as

\footnotetext{
${ }^{3}$ Inter-American Court of Human Rights, Case of Velásquez Rodríguez v Honduras, 1988, para. 172.

${ }^{4}$ Inter-American Court of Human Rights, Case of Kaliña \& Lokono Peoples v Suriname, 2015, paras. 224-226.

${ }^{5}$ Inter-American Court of Human Rights, “Obligaciones estatales en relación con el medio ambiente en el marco de la protección y garantía de los derechos a la vida y a la integridad personal - interpretación y alcance de los artículos 4.1 y 5.1, en relación con los artículos 1.1 y 2 de la convención americana sobre derechos humanos." Opinión Consultiva OC-23/17, 2017, paras. 154-5.
} 
a 'minimum baseline', a 'starting point' and 'a dynamic and evolving conceptual basis'. ${ }^{6}$

The Guiding Principles were also endorsed by the OAS General Assembly in 2014, which urged member states to disseminate them as widely as possible (Organization of American States General Assembly 2014).

It should be noted that at a global level the GPs have also been the object of substantial scholarly criticism. Wettstein feels that they lack an ethical dimension (Wettstein 2015), while Bilchitz and Deva hold that the bar for the duties of corporations was set too low (Deva and Bilchitz 2013). Blitt remarks that they take inadequate account of crucial treaties such as CEDAW (Blitt 2012, 44-46); Beckers effectively summarises common concerns that they are overly corporatised:

Rather than pushing the legal boundaries of international human rights law further to bring states under a stronger duty, [the GPS] engage in what two observers call 'framing tactics' that 'are designed to facilitate a familiarity and comfort with the framework that will promote voluntary buy-in and elite management with the new international regime, whilst allowing a large degree of creative ambiguity about what such engagement must in fact entail (Beckers 2020, 18).

In their defence, it should be noted that John Ruggie himself viewed the GPs as merely 'the end of the beginning' (United Nations Human Rights Council 2011a, Introduction, para. 13); the consensusbased framework that he created is not a solution in itself but 'set[s] the stage for further elaboration of industry-specific standards and mechanisms...to protect and respect human rights' (Nolan 2016, 44).

As mentioned above, a majority of inhabitants of the lithium triangle self-identifies as indigenous and the region includes governmentally recognised indigenous territories. To fully appreciate

${ }^{6}$ Inter-American Commission on Human Rights, Special Rapporteurship on Economic, Social, Cultural and Environmental Rights (REDESCA), 2019, "Business and Human Rights: Inter-American Standards", paras. 10-11. 
the local context, it is therefore important to also analyse the relationship between the GPs and indigenous rights.

Clavero (Clavero 2012), in a strong critique of the UN's business and human rights approach, comments that the GPs do not make reference to indigenous rights, and the ILO treaties cited as a part of the minimum standard for corporate respect for human rights (United Nations Human Rights Council 2011a, para. 12) do not include the key indigenous rights treaty ILO Convention 169 (International Labour Organization 1989). However, although it is accurate that the GPs do not mention indigenous rights, they do require businesses to 'respect the human rights of individuals belonging to specific groups or populations that require particular attention, where they may have adverse human rights impacts on them' and specifically cite indigenous peoples as an example (United Nations Human Rights Council 2011a, para. 12).

Assessing the applicability of the GPs to an indigenous context requires thinking about power imbalance. In one sense, the adoption of voluntary standards such as the GPs can be seen as a contrast to traditional ‘top-down' hard law (Groulx Diggs, Regan, and Parance 2019, 344), and their emphasis on risks to rights-holders is a significant step away from standard corporate risk evaluations (OECD 2018, 15; Harrison 2011, 176). This reflects a view that those rightsholders should be considered not as passive victims of impacts but as active participants in the human rights due diligence process (Boersma 2017, 1272). Nevertheless, the problem with companies self-reporting is that the result is still top-down in nature: it is the company that decides whether or not it is likely to impact the rights under examination. Ruggie's concept of due diligence as 'a tool which assists corporations in fulfilling their responsibility to respect human rights' (Michalowski 2013, 221) prompts the question: is the tool in the wrong hands?

In their defence, the Guiding Principles do affirm that identification of human rights impacts should include 'meaningful 
consultation' with those potentially impacted (United Nations Human Rights Council 2011a, para. 18). What does this actually signify? Rather than debating a legal definition of meaningfulness, the requirement is perhaps best summarised by an industry participant in a study: 'You have to find a way to ask rights-holders about how they are impacted, rather than asking companies if they are impacting human rights' (Norton Rose Fulbright and British Institute of International and Comparative Law 2018, 33).

International indigenous law with its more bottom-up focus seems to be ahead of business and human rights instruments such as the GPs on these measures. While James Anaya, UN Special Rapporteur on the Situation of Human Rights and Fundamental Freedoms of Indigenous People, affirmed that when a private company is to undertake resource extraction, the responsibility for consultation lies with states (United Nations Human Rights Council 2009, para. 54), he nevertheless noted that extractive companies should undertake human rights due diligence to ensure that indigenous rights are not being impacted (United Nations Human Rights Council 2013b, paras. 52-57) and should not accept extractive concessions from states in situations where prior consultation and consent are absent (para. 55). On the ground, the importance of company-community processes is paramount: 'due diligence will ordinarily entail companies endeavouring to engage in their own consultations with indigenous and tribal peoples to ensure respect for their rights and free, prior and informed consent' (Anaya, Evans, and Kemp 2017, 6). The strong focus in international indigenous law on the rights to consultation, consent and self-determination raise the bar for Guiding Principles concepts such as human rights due diligence, offer more scope for incorporation of positive human rights impacts into the process and allow for a more bottom-up approach that strengthens protections for rights-holders. 


\section{State engagement with business and human rights}

The three nations of the lithium triangle - Argentina, Bolivia, and Chile - show differing levels of engagement with business and human rights issues and the Guiding Principles.

The UN Working Group on Business and Human Rights, established with a mandate to promote the dissemination and implementation of the GPs (United Nations Human Rights Council 2011 b, para. 6), identifies national action plans ('NAPs') as the 'most promising' means for states to track their implementation of the Guiding Principles (United Nations General Assembly 2015, paras. 22, 71-73) and their obligatory adoption by states has been recommended as part of any business and human rights treaty (Schutter 2016). However it has also been highlighted that NAPs are a policy tool of limited effectiveness unless combined with an integrated program of regulatory and legislative measures (Cantú Rivera 2019).

\section{a. Argentina}

A National Action Plan on human rights was formulated by the Macri government in 2017 and was seen as a belated means of implementing the relevant recommendation from the 1993 Vienna Declaration and Programme of Action (Ministerio de Justicia y Derechos Humanos (Argentina) 2017, 7, 15; United Nations General Assembly 1993, para. II.C.71). It revolves around five key themes and sets out a series of actions to be accomplished by various branches of federal and provincial government. One of the sub-themes is business and human rights; actions proposed include meetings and working groups designed to strengthen coordination within government and between government and the private sector. The creation of a National Action Plan on business and human rights is another action; the beginning of this process was announced in 2018 (Secretaría de 
Derechos Humanos y Pluralismo Cultural (Argentina) 2018) and at time of writing the document was still being drafted.

Further state engagement with business and human rights includes the establishment of a National Contact Point (NCP) as specified by the OECD Guidelines for Multinational Enterprises (OECD 2011, 68), to which Argentina adheres. Participating states are obliged to set up the NCP in order to promote the Guidelines and to establish a mechanism that allows NGOs and others to submit complaints concerning alleged breaches of the Guidelines.

\section{b. Chile}

Chile developed a National Plan on human rights in 2017 (Gobierno de Chile 2017b), something that led from the creation of a Human Rights Sub-Secretariat in 2016; as in Argentina the National Plan is considered to be a fulfilment of the Vienna Declaration recommendation. It consists of over 600 actions to be undertaken from 2018 to 2021, divided into 15 themes, one of which is business and human rights.

A separate National Action Plan (NAP) on business and human rights was created in 2017 (Gobierno de Chile 2017a), though this was designed to be superseded by an updated version, ${ }^{7}$ a process that is included in the National Plan on Human Rights (Gobierno de Chile $2017 \mathrm{~b}, 256)$ but that had not yet happened at time of writing.

Chile's current NAP defines measures to be taken by various institutions on 16 themes, categorised under the three-pillar structure of the Guiding Principles. Similarly, the National Plan includes business and human rights measures divided among three goals: to promote a human rights culture in public and private companies, to strengthen the accountability system of companies and to improve

$7 \underset{\text { National Action Plans on }}{\text { <https://globalnaps.org/country/chile>. }}$ 
the level of technical assistance and oversight of the state (Gobierno de Chile 2017b, 255-63).

Chile's national human rights institution has criticised the current National Action Plan, noting that there was very little participation from private companies or measures prescribed for them; and little scope for legal reform (Instituto Nacional de Derechos Humanos (Chile) 2018, 148). Observatorio Ciudadano critiques the NAP from the standpoint of the Guiding Principles, commenting that despite treaty obligations to adopt domestic legal measures to protect rights from corporate impact, the document is very weak on this. The report critically cites the NAP's less-than-robust phrasing that 'legislative changes are processes involving lengthy discussion' (Aylwin, Didier, and Guerra 2019, 17). As Cantú Rivera comments, NAPs can function well in getting different government organs to pull in the same direction on rights issues (Cantú Rivera 2018, 204) but if they do not generate legal obligations for companies or clarify state duties beyond the formulation of the NAP itself they risk ineffectiveness (Cantú Rivera 2018, 207, 216).

Like Argentina, Chile also has an OECD National Contact Point (NCP). Though the NCP has been involved in eleven business and human rights cases (see, for example: Rosado Marzán 2016), it has also been criticised as being under-resourced and had the independence of its staff, who hold government positions in the Ministry of Foreign Affairs, questioned (Instituto Nacional de Derechos Humanos (Chile) 2018, 150).

Nevertheless, there have been significant developments in the business and human rights field at an institutional level. An interviewee observed that the Ministry of the Interior had recently adopted the OECD Guidelines, a clear sign for smaller ministries to follow suit. They also commented that the Confederation of Production and Commerce, a rather conservative organisation, had published guidelines recommending that its members adopt a business human rights framework, and that the Santiago stock 
exchange was moving towards adopting sustainability initiatives similar to those of the Dow Jones. ${ }^{8}$

\section{c. Bolivia}

Although Bolivia was influential in the birth of the business and human rights treaty process (United Nations Human Rights Council 2014), there has not been significant government engagement with the Guiding Principles or other business and human rights frameworks. Bolivia's 2008 National Action Plan on human rights predates the GPs and does not specifically address the issue (Ministerio de Justicia (Bolivia) 2008); nor does Bolivia's most recent Universal Periodic Review (United Nations Human Rights Council 2019).

In part this may be that in recent years the state has considered that it adequately protects its citizens from foreign multinationals. In reference to 'The Open Veins of Latin America', Galeano's famous book on the pillage of the region's natural resources (Galeano 1970), de Sousa Santos has described modern Bolivia as a 'closed-vein-state' due to the Morales administration's determination to keep most of the proceeds of exploitation of the state's mineral wealth within the country (de Sousa Santos 2010, 114). For example, under the Moralesera revised mining law, certain mining rights were only granted under the condition that the state be a majority partner in the enterprise (Gobierno de Bolivia 2014, para. 73).

Nevertheless, though the series of reports published by the national ombudsman from 2012 to 2015 on the state of human rights in the nation do not raise the question of business impacts on rights (Defensoría del Pueblo (Bolivia) 2015), another report on indigenous rights criticises government policy allowing oil companies to operate in protected areas (Defensoría del Pueblo (Bolivia) 2016, 70). Similarly, a fact-finding visit in 2014 noted that lack of attention to the

${ }^{8}$ Interview 72892071. 
Guiding Principles was prejudicing indigenous rights (Horvath, Lazala, and Romero 2014), and a Special Rapporteur noted after a 2012 visit that a large number of mining concessions were granted by the government without prior consultation with indigenous groups (United Nations Human Rights Council 2013a, para. 31, 58). A draft law enshrining prior consultation with these groups was never passed, but, interestingly, it proposed that agreements between companies and communities would be legally binding (RESOLVE 2015, 50).

\section{Company engagement with business human rights frameworks}

The empirical analysis presented here is part of a longer-term study into corporate engagement with rights norms in the lithium triangle. The study consists of 57 semi-structured interviews conducted in 2019 and 2020 with representatives of indigenous communities, lithium companies, government, NGOs and civil society experts in Argentina and Chile. ${ }^{9}$

In the lithium triangle, there are currently four companies in production - with another very close to production - and over 50 projects at various stages from prospecting to pre-production. Interviews were conducted with companies at several levels, allowing an understanding of how company approaches have changed both through the life cycle of a project and as industry best practice has evolved over time.

Among lithium triangle companies, none had explicitly adopted the Guiding Principles as a boardroom-level standard. ${ }^{10}$ In fact, a majority of executive-level interviewees did not appear to have heard

\footnotetext{
${ }^{9}$ While the broader study of which this paper is a part will encompass all three lithium triangle countries, the Covid-19 crisis meant that fieldwork in Bolivia was unfortunately but necessarily postponed. The empirical part of this paper therefore only includes interviews from Argentina and Chile.

${ }_{10}$ Although one is currently in the process of conducting a human rights impact assessment influenced by the GPs.
} 
of them at all. However, that does not necessarily represent a failure: this section will show that their influence has certainly been felt indirectly in the region.

Part of the reason for the low adoption of the GPs among lithium triangle companies is a corporate reluctance to frame issues in terms of human rights. This appears to be related to the politicisation of the term in Argentina and Chile, and its association with their periods of dictatorship. Though, as illustrated above, lithium triangle states are employing human rights language at the level of policy, companies operating in the region are not. Interviewees from lithium mining companies in both Argentina and Chile commented that the term 'human rights' was politically charged and immediately invoked a return 'straight to the 1970 s'. ${ }^{11}$ Nevertheless, it can be imagined that increased state use of the term in the business context - NAPs are a good example - will have a normative effect on corporations operating in these countries and increase the use of rights language in corporate processes.

Nevertheless, as the following empirical data will show, a number of sustainability frameworks appear to have more currency than the GPs in boardrooms and among corporate personnel on the ground. The fact that many of these frameworks are explicitly based on the GPs suggests that the instrument is having a significant indirect influence on the industry.

A representative of Chile's mining ministry considered that, while the country's NAP on business and human rights was aimed at collating compliance actions for the Guiding Principles, the OECD Guidelines were currently more influential than the GPs in terms of disseminating due diligence principles to companies, and the associated National Contact Point provided an important remedial mechanism as mentioned above. They also cited the International Council on Mining and Minerals (ICMM) as a useful source of material

${ }^{11}$ Interview 82940614; Interview 98976075. 
for companies to guide their sustainability reporting. ${ }^{12}$ The ICMM is an industry-only body that brings together major mining companies who sign up to ten principles - part of a larger sustainable development framework - which include a commitment to respect human rights and to support the Guiding Principles (International Council on Mining and Metals, n.d., para. 3). Companies are obliged to report on adherence to the principles. The ICMM has also published human-rights-specific guidance for companies (International Council on Mining and Metals 2009).

A company executive named the international frameworks and instruments that they were engaging with as two key indigenous rights provisions (ILO Convention 169 and the United Nations Declaration on the Rights of Indigenous Peoples) as well as the OECD Guidelines and the Initiative for Responsible Mining Assurance (IRMA). ${ }^{13}$ IRMA is a multi-stakeholder framework whose Standard for Responsible Mining (Initiative for Responsible Mining Assurance (IRMA) 2018) aims to set a global standard for certification of environmentally and socially responsible practice. As well as compliance with local law, it mandates community engagement and human rights due diligence among many other procedures. The human rights element is heavily based on the Guiding Principles. Though engagement from the sector has so far been limited, the Standard represents the most holistic and in-depth approach to issues within the extractive industries yet developed.

In comparison, the Global Reporting Initiative was seen by companies as being a lower bar because it lacked the compulsory third party analysis of the IRMA Standard ${ }^{14}$ and because its standards were too static and took a long time to alter. ${ }^{15}$ By contrast, the analysis performed to rate companies for the Dow Jones Sustainability Indices (DJSI) was seen as one of the most superior because it closely

\footnotetext{
12 Interview 82444430.

${ }^{13}$ Interview 40839731.

14 Ibid.

${ }^{15}$ Interview 49153636.
} 
monitored emerging best practice and quickly incorporated that as a standard for succeeding years, allowing companies to become aware of what systems and processes industry leaders were implementing. ${ }^{16}$ The human rights element of the company questionnaires used to evaluate the DJSI are also based on the GPs, assessing whether a company has human rights policies, due diligence processes, risk assessments and transparency in this arena (RobecoSAM 2016).

The International Finance Corporation's Performance Standards on Environmental and Social Sustainability set benchmarks in eight areas that are used as criteria for private sector lending by the organisation (International Finance Corporation 2012). Corporate responsibility to respect human rights is explicitly made reference to in the introduction, which states that each of the eight standards has human rights dimensions. These standards have become a key benchmark in the mining industry generally (Kemp and Owen 2017, 164; Owen and Kemp 2017, 6) and the related Equator Principles (The Equator Principles 2020) extend this framework to nearly a hundred financial institutions, providing a minimum standard for due diligence and monitoring. The due diligence requirement specifically references the GPs (p. 3). These instruments collectively cover over 90 percent of project financing in emerging markets (United Nations Development Program and United Nations Environment 2018, 50) and have therefore become very significant to the policies of larger mining companies, whose projects nearly always require substantial loans to commence operations. At least one major bank loan to a lithium triangle company was made under IFC/Equator Principles standards. ${ }^{17}$

From this brief survey we can see that despite the lack of specific adoption of the Guiding Principles, companies in the lithium triangle are increasingly coming under their influence in an indirect manner via other instruments and frameworks. Adoption of these frameworks

16 Ibid.

17 Interview 75360584. 
appears to be increasing - one company referred to a rising international standard that created a pressure to do $\mathrm{so}^{18}$ - and companies are also influenced in what frameworks to adopt by companies in their supply chain. Lithium triangle companies referred to growing expectations from those who purchased their product; ${ }^{19}$ it is also notable that automotive and battery companies have shown an interest in acquiring direct stakes in lithium companies in order to guarantee both supply and procurement transparency. ${ }^{20}$

\section{The Guiding Principles and the Nature of Mining}

Another relevant factor in the adoption of the GPs and business human rights instruments in the lithium triangle is one that also applies to the wider extractive industry: the nature of mining and the way that extractive projects typically develop.

The responsibilities and processes set out by the GPs and other frameworks appear designed to be integrated into the systems of large, well-established corporations with existing sustainability or corporate social responsibility departments. Human rights due diligence and impact assessments can thus be incorporated into existing procedures.

However, in the mining industry the capacity to undertake this type of assessment generally appears at a late stage in the project. Fewer than one percent of sites explored ever make it to production (Department of Earth Resources of Victoria 2021), meaning companies are unlikely to commit resources to human rights processes until they reach the production phase.

\footnotetext{
${ }^{18}$ Interview 40839731.

${ }^{19}$ E.g., Interview 24684918, Interview 94532117, Interview 72182748.

${ }^{20}$ For example, Toyota Tsusho, a trading arm of the car manufacturer, owns $25 \%$ of the Sales de Jujuy lithium extraction company, and $15 \%$ of its co-shareholder Orocobre. See Orocobre, Annual Report 2019, 141; and Sales de Jujuy, Company Brochure, 3, both available at www.salesdejujuy.com
} 
For the same reason, there is usually an issue of capacity. Mining projects usually begin as very small-scale operations. In the lithium triangle, though Chile and Bolivia exert a somewhat more centralised control over lithium extraction, initial prospecting at salar sites in Argentina is often literally conducted by one geologist and his/her truck. In time, a concession to the site may be acquired by a small mining company, which, if feasibility studies are promising, then partners or is taken over by a larger company as capitalisation for the project is sought. This process of scaling up as viability increases means that responsibility for environmental and social aspects of the operation is often vested in employees likely to be mining engineers with little if any specialisation in that field; it is usually only when larger companies become involved that dedicated workers such as sustainability or community relations experts are present.

One company employee noted that best practice standards in the industry could only be realistically achieved by a large company with long experience, because it took time and capacity to build the advanced systems and processes required.

At a small-scale mining company, you've generally got a COO, a CFO and an investor relations person; that's all there is. And so [the investor relations person] suddenly has got to upskill on, for example, climate-related financial disclosures and how to prepare a response on climate change in what they're doing and "what are scope one and scope two emissions anyway?". For them it's all complete jargon, and then you've got the UN Guiding Principles and grievance. "What's a grievance mechanism? Access to remedy, what does that even mean?" The immediate reaction is "but we're not hurting anyone's rights". ${ }^{21}$

A similar point in the context of capacity was made by another company executive, who commented:

${ }^{21}$ Interview 37800868. 
The majority of these principles and norms are international. The company lawyer is probably expert on the national legal framework, but it's unlikely they'll have much knowledge of the international norms on, say, business and human rights. Not impossible but unlikely. ${ }^{22}$

In the business human rights framework, company capacity is considered to be of relevance in potentially creating different levels of responsibilities. For example, Article 14 of the Guiding Principles states:

The responsibility of business enterprises to respect human rights applies to all enterprises regardless of their size, sector, operational context, ownership and structure. Nevertheless, the scale and complexity of the means through which enterprises meet that responsibility may vary according to these factors... (United Nations Human Rights Council 2011a, para. 14)

The Commentary to the Article quotes capacity as being a criterion for a 'different form' of compliance with operational requirements (United Nations Human Rights Council 2011a, paras. 14, Commentary). Similarly, the OECD Guidelines acknowledge that capacity may mean corporations are less able to comply with all recommendations, though they are encouraged to (OECD 2011, 18).

Various extractive-specific frameworks such as the IRMA and ICMM standards mentioned above are obviously more tailored to the specific nature of mining, but also have little to offer smaller companies. From the analysis above, it seems that companies would benefit from there being operationalised pathways taking gradual steps towards compliance with these frameworks. From the evidence in the lithium triangle, it seems that companies only begin to consider adopting these frameworks once in production and well-established.

${ }^{22}$ Interview 42589358. 
This of course means that there may already be unaddressed and ongoing human rights impacts from their activities.

\section{Pathways for increased state and community involvement}

While there is likely to be increased pressure from society and the supply chain for companies to adhere to business human rights or sustainability frameworks, there are other potential pathways to engender better and earlier engagement. This section discusses the potential for greater state and community involvement in due diligence and other rights-focused processes in light of lessons learned from state use of the environmental impact assessment process and increasing prominence of indigenous rights.

Though in Bolivia there is stricter state oversight, in Argentina and Chile, the most rigorous governmental analysis of a potential mining project comes via evaluations of its environmental impact.

The national environmental standards required by the Argentine constitution are principally established by the General Environmental Law of 2002 (Gobierno de Argentina 2002). This sets out, in Articles 11 to 13, the principles of the system of project evaluation. The Evaluation of Environmental Impact has as its main pillar an environmental impact assessment (EsIA) which is undertaken by the company or entity involved and includes a mechanism for citizen participation.

In Chile, the 1994 Environmental Framework Law (Law 19300) created the National Environmental Commission (CONAMA); a 2010 modification (Law 20417) created the Ministry of the Environment. The Environmental Impact Evaluation System (SEIA) dates from 1997 but the current version was established by that ministry in $2012^{23}$ and

23 Ministerio del Medio Ambiente, Decreto 40: Aprueba reglamento del Sistema de Evaluación de Impacto Ambiental, 30 Oct 2012, became law 24 December 2013. 
requires (as set down by Article 10 of the Framework Law) projects to present either an Environmental Impact Declaration (DIA) or, for potentially more serious impacts, an Environmental Impact Assessment (EIA). ${ }^{24}$

The EIA (compulsorily) and DIA (at the discretion of the regional authority) include a process of citizen participation. Additionally, if the requirements of Article 6 of ILO Convention 169 are met, a process of indigenous consultation, incorporated into the SEIA, is triggered. This became law under Decreto 40 in late 2013 but had already been practised to some extent on an ad-hoc basis (Donoso 2017).

Given that in both countries social dimensions of impact are assessed to some degree within the environmental impact system, there is therefore significant scope for lithium triangle states to introduce specific human rights due diligence and impact assessment requirements into the environmental impact assessment process. These could be explicitly based on the GPs and/or other business human rights frameworks, though the realistic capacity of junior mining companies discussed above should be taken into account.

Such a governance action would potentially have a dual benefit beyond that experienced by rights-holders. Firstly, obliging mining companies to undertake human rights processes at a comparatively early stage of the project is likely to have some normative effect on company culture and might ease the transition towards fuller and earlier compliance with business and human rights frameworks. Companies in the lithium triangle nearly all implement detailed community relations strategies at a comparatively early stage of operations and integrating human-rights-specific processes into these is likely to safeguard rights to a greater degree.

Secondly, this kind of regulation could be seen as an intermediate step in the process described by Groulx Diggs et al whereby voluntary standards and principles gradually become

${ }^{24}$ Article 4. 
sufficiently accepted that they eventually serve as a model for national legislation (Groulx Diggs, Regan, and Parance 2019, 345). Incorporating international business and human rights standards into environmental governance procedures could pave the way for the establishment of broader legislative incorporation of them.

The relevance of the GPs and other business and human rights frameworks to the mostly indigenous communities of the lithium triangle is contemplated above. In the region, the communities are generally very aware of certain rights, regularly citing provisions of international indigenous law, particularly ILO Convention 169, which has been ratified by all three lithium triangle states. In particular, the right to consultation is seen as key to self-determination of development priorities. As well as being integral to selfdetermination, consultation is a 'gatekeeper right' that can prevent and mitigate impacts from extractive projects on a whole suite of other rights.

International indigenous law has been described as a 'tool of reempowerment' of indigenous peoples (Di Blase and Vadi 2020, 19) and this is readily apparent in the lithium triangle. As one community leader phrased it,

Convention 169 establishes the autonomy of communities, so we have gone further than knocking on the state's door... to a certain extent we have exercised our autonomy regardless of whether the state wishes or not to recognize it. ${ }^{25}$

In the lithium triangle, indigenous rights instruments appear to give local communities a far more relevant framework to the reality of their lives and their intimate connection to territory than do human rights treaties. The fact that indigenous participation was central to the formulation of those instruments gives them a bottom-up legitimacy that is crucial to their empowering capabilities. In a predominantly indigenous context, it is perhaps necessary for

${ }^{25}$ Interview 96964167. 
international human rights law - and therefore business human rights instruments such as the GPs - to be interpreted via the lex specialis that indigenous rights instruments provide.

Several instruments in the business and human rights space, such as the Equator Principles ${ }^{26}$ and IRMA Standard, ${ }^{27}$ have a focus on indigenous consultation and free, prior and informed consent, but it would be desirable for the broader panorama of indigenous rights as laid out in ILO Convention 169 and the UNDRIP in particular, to be considered.

As discussed above, the GPs lag in some ways behind indigenous law in terms of the latter's more bottom-up nature. In what is a good example of community empowerment in the lithium triangle, communities have insisted on conducting their own monitoring of environmental impact - independent of company assessments - in order to understand the risks to their water and livelihoods from extractive activity. We see here the principles of self-determination and bottom-up rights engagement, facilitated by international indigenous law, at work.

Similarly, while the GPs contemplate a consultative due diligence process conducted by the company, a more effective protection for rights on the ground would be for communities to be actively involved in gauging, predicting, and measuring rights impacts. An effective business and human rights approach should empower communities as much as possible rather than including them only as part of a corporate consultation and as objects of an impact assessment study.

\section{Conclusions}

The preceding analysis demonstrates that the success or otherwise of the Guiding Principles is not just about implementation,

\footnotetext{
${ }^{26}$ Principle 5.

27 Principle 2.2.
} 
or direct adoption by companies. The integration of elements of the GPs into other business and human rights frameworks, many of them industry-specific, means that their influence is more pervasive than it might otherwise seem given the rather low specific awareness of them among lithium mining companies. These parameters that the GPs establish for other, more context-specific, instruments are a major strength, particularly in an environment where companies are facing increasing pressure to demonstrate their sustainability.

However, the GPs are by no means a perfect instrument. While they are potentially adaptable to different corporate contexts, this brief examination of the lithium triangle illustrates that their failure to give sufficient agency to rights holders within the framework means that communities may view them as less relevant to their needs than instruments which take more account of indigenous rights. A more bottom-up approach that takes into account the views and needs of rights holders is needed for companies to adequately address rights concerns and impacts.

It has been shown that expectations of corporations from civil society and companies in the lithium supply chain have risen and continue to rise. However, these expectations are not necessarily focused on human rights per se but more broadly on sustainability. A question for the business human rights movement going forward is how to manage this: to incorporate human rights into broader assessments of sustainability without diluting them. As illustrated by their inclusion in various other instruments and frameworks, the Guiding Principles provide an ideal mechanism for the former part of this challenge, but as for the latter, it will be up to states to ensure that the GPs are implemented robustly, with respect for all human rights, including those specifically relating to indigenous populations or other groups covered by specific rights instruments.

\section{References}


Anaya, James S., Jessica Evans, and Deanna Kemp. 2017. "Free, Prior and Informed Consent (FPIC) within a Human Rights Framework: Lessons from a Suriname Case Study." RESOLVE FPIC Solutions Dialogue. Washington DC.

Aylwin, José, Marcel Didier, and Felipe Guerra. 2019. "Plan de Acción Nacional de Derechos Humanos y Empresas: Análisis crítico desde la sociedad civil." Observatorio Ciudadano.

Babidge, Sally. 2016. "Contested Value and an Ethics of Resources: Water, Mining and Indigenous People in the Atacama Desert, Chile." The Australian Journal of Anthropology 27: 84-103.

- 2018. "Sustaining Ignorance: The Uncertainties of Groundwater and Its Extraction in the Salar de Atacama, Northern Chile." Journal of the Royal Anthropological Institute 00: $1-20$.

Beckers, Anna. 2020. "From Corporate Personality to Corporate Governance: The Transformation of International Human Rights Protection in Corporate Governance Structures." In Human Rights and Global Governance, edited by Nehal Bhuta and Rodrigo Vallejo. Oxford: Oxford University Press.

Blitt, Robert C. 2012. “Beyond Ruggie’s Guiding Principles on Business and Human Rights: Charting an Embracive Approach to Corporate Human Rights Compliance.” Texas International Law Journal 48: 33-62.

Boersma, Martijn. 2017. "Changing Approaches to Child Labour in Global Supply Chains: Exploring the Influence of MultiStakeholder Partnerships and the United Nations Guiding Principles on Business and Human Rights." UNSW Law Journal 40: 1249 .

Cantú Rivera, Humberto. 2018. La responsabilidad de las empresas en materia de derechos humanos. Comisión Nacional de los Derechos Humanos.

_ 2019. "National Action Plans on Business and Human Rights: Progress or Mirage?" Business and Human Rights Journal 4 (2): 213-37.

Clavero, Bartolomé. 2012. "Principios contra garantías: Empresas transnacionales y pueblos indígenas en el orden internacional de 
los derechos humanos tras 2011." Revista Latinoamericana de Derecho y Políticas Ambientales 2 (August): 63-92.

Defensoría del Pueblo (Bolivia). 2015. "El ejercicio de los derechos humanos en el Estado Plurinacional de Bolivia: Informe 2015.”

2016. "Sin los pueblos indígenas no hay estado plurinacional: Situación de los derechos de los pueblos indígena originario campesinos en el estado plurinacional de Bolivia.

Department of Earth Resources, Government of Victoria, Australia: "Understanding minerals exploration" (2021) https:// earthresources.vic.gov.au/community-and-landuse/understanding-exploration

Deva, Surya, and David Bilchitz. 2013. "The Human Rights Obligations of Business: A Critical Framework for the Future." In Human Rights Obligations of Business: Beyond the Corporate Responsibility to Respect?, edited by Surya Deva and David Bilchitz, 1. New York: Cambridge University Press.

Di Blase, Antonietta, and Valentina Vadi. 2020. "Introducing the Inherent Rights of Indigenous Peoples." In The Inherent Rights of Indigenous Peoples in International Law, edited by Antonietta Di Blase and Valentina Vadi, 15-39. Rome: University of Rome 3 Press.

Diouf, Boucar, and Ramchandra Pode. 2015. "Potential of LithiumIon Batteries in Renewable Energy." Renewable Energy76 (April): 375-80. https://doi.org/10.1016/j.renene.2014.11.058.

Donoso, Sebastián. 2017. "Tres años de consulta indígena en el SEIA.” Minería Chilena (blog). January 10, 2017. www.mch.cl/columnas/tres-anos-consulta-indigena-seia/.

Flexer, Victoria, Celso Fernando Baspineiro, and Claudia Inés Galli. 2018. "Lithium Recovery from Brines: A Vital Raw Material with a Potential Environmental Impact in Its Mining and Processing." Science of the Total Environment 639: 1188-1204.

Fornillo, Bruno. 2015. Geopolítica del Litio: Industria, Ciencia y Energía en Argentina. Buenos Aires: Editorial el Colectivo. Territorios. Buenos Aires: Editorial el Colectivo. 
Galeano, Eduardo. 1970. Las venas abiertas de América Latina. Montevideo: Ediciones del Chanchito.

Göbel, Barbara. 2013. "La minería del litio en la Puna de Atacama: interdependencias transregionales y disputas locales." IberoamericanaXIII (49): 135-49.

Gobierno de Argentina. 2002. Ley 25675.

Gobierno de Bolivia. 2014. "Ley 535 de Minería y Metalurgia.”

Gobierno de Chile. 2017a. "Plan de Acción Nacional de Derechos Humanos y Empresas de Chile."

_. 2017b. "Primer Plan Nacional de Derechos Humanos."

Groulx Diggs, Elise, Milton C. Regan, and Beatrice Parance. 2019. "Business and Human Rights as a Galaxy of Norms." Georgetown Journal of International Law 50 (2): 309-62.

Gundermann, Hans, and Barbara Göbel. 2018. "Comunidades indígenas, empresas del litio y sus relaciones en el Salar de Atacama." Chungara Revista de Antropología Chilena 50 (3): 47186.

Harrison, James. 2011. "Human Rights Measurement: Reflections on the Current Practice and Future Potential of Human Rights Impact Assessment." Journal of Human Rights Practice 3 (2): 162-87.

Horvath, Eniko, Mauricio Lazala, and Amanda Romero. 2014. "Business \& Human Rights Standards Fail Indigenous Peoples in Bolivia \& Chile." OpenDemocracy (blog). August 22, 2014. www.opendemocracy.net/en/openglobalrights-openpageblog/business-human-rights-standard/.

Initiative for Responsible Mining Assurance (IRMA). 2018. "IRMA Standard for Responsible Mining IRMA-STD-001."

Instituto Nacional de Derechos Humanos (Chile). 2018. "Informe Anual: Situación de los Derechos Humanos en Chile 2018."

International Council on Mining and Metals. 2009. "Human Rights in the Mining and Metals Industry: Overview, Management Approach and Issues." 
n.d. “ICMM 10 Principles.” www.icmm.com.

International Finance Corporation. 2012. "Performance Standards on Environmental and Social Sustainability."

International Labour Organization. 1989. "Convention 169 Indigenous and Tribal Peoples", entered into force 5 Sep 1991.

Kazimierski, Martín. 2019. “Transición energética, principios y retos: la necesidad de almacenar energía y el potencial de la batería ionlitio.” In Litio en Sudamérica: Geopolítica, Energía, Territorios, edited by Bruno Fornillo, 25-49. Buenos Aires: Editorial el Colectivo.

Kemp, Deanna, and John R. Owen. 2017. "Corporate Readiness and the Human Rights Risks of Applying FPIC in the Global Mining Industry." Business and Human Rights Journal 2 (1): 163-69. https://doi.org/10.1017/bhj.2016.28.

Levin Sources. 2017. "Solar Photovoltaic and Energy Storage in the Electric Grid."

Liu, Wenjuan, Datu B. Agusdinata, and Soe W. Myint. 2019. "Spatiotemporal Patterns of Lithium Mining and Environmental Degradation in the Atacama Salt Flat, Chile." International Journal of Applied Earth Observation and Geoinformation 80: 145-56. https://doi.org/10.1016/j.jag.2019.04.016.

Marchegiani, Pia, Jasmin Höglund Hellgren, and Leandro Gómez. 2019. "Lithium Extraction in Argentina: A Case Study on the Social and Environmental Impacts." Buenos Aires: Fundación Ambiente y Recursos Naturales (FARN).

Michalowski, Sabine. 2013. "Due Diligence and Complicity: A Relationship in Need of Clarification." In Human Rights Obligations of Business: Beyond the Corporate Responsibility to Respect?, edited by Surya Deva and David Bilchitz, 218. New York: Cambridge University Press.

Ministerio de Justicia (Bolivia). 2008. "Plan nacional de acción de derechos humanos Bolivia para vivir bien 2009-2013."

Ministerio de Justicia y Derechos Humanos (Argentina). 2017. "Primer Plan Nacional de Acción en Derechos Humanos 2017-2020.” 
Nacif, Federico, and Miguel Lacabana, eds. 2015. $A B C$ del litio sudamericano: Soberanía, ambiente, tecnología e industria. Buenos Aires: Ediciones CCC.

Nolan, Justine. 2016. "Mapping the Movement: The Business and Human Rights Regulatory Framework." In Business and Human Rights: From Principles to Practice, edited by Dorothée Baumann-Pauly and Justine Nolan, 32-51. Abingdon: Routledge.

Norton Rose Fulbright, and British Institute of International and Comparative Law. 2018. "Making Sense of Managing Human Rights Issues in Supply Chains: 2018 Report and Analysis." https:/ / www.biicl.org/documents/1939_making_sense_of_man aging_human_rights_issues_in_supply_chains_-

_2018_report_and_analysis_-_full_text.pdf?showdocument=1.

OECD. 2011. “OECD Guidelines for Multinational Enterprises 2011 Edition.” OECD Publishing. https://doi.org/10.1787/mne-2002en.
2018. "OECD Due Diligence Guidance for Responsible Business Conduct." OECD Publishing. http://mneguidelines.oecd.org/OECD-Due-Diligence- Guidance-for-Responsible-Business-Conduct.pdf.

Organization of American States General Assembly. 2014. Promotion and Protection of Human Rights in Business. Vol. AG/doc.5452/14 rev.1.

Owen, John R., and Deanna Kemp. 2017. Extractive Relations: Countervailing Power and the Global Mining Industry. Abingdon: Routledge.

RESOLVE. 2015. "From Rights to Results: An Examination of Agreements between International Mining and Petroleum Companies and Indigenous Communities in Latin America."

RobecoSAM. 2016. “DJSI 2016: Review Results.”

Rosado Marzán, César F. 2016. "NCP Starbucks Decision Helps Advance Compliance with OECD Guidelines." International Labour Rights Case Law2: 175-79.

Schutter, Olivier de. 2016. "Towards a New Treaty on Business and Human Rights." Business and Human Rights Journal 1 (1): 41-67. https://doi.org/10.1017/bhj.2015.5. 
Secretaría de Derechos Humanos y Pluralismo Cultural (Argentina). 2018. "Se presentó el Plan de Acción de Empresas y Derechos Humanos." https://www.argentina.gob.ar/noticias/sepresento-el-plan-de-accion-de-empresas-y-derechoshumanos.

Sousa Santos, Boaventura de. 2010. Refundación del Estado en América Latina. Perspectivas desde una epistemología del Sur. Lima: Instituto Internacional de Derecho y Sociedad.

Sticco, Marcelo. 2018. “¿itio al Agua!” Pulso Ambiental 10 (August): $17-18$.

“The Equator Principles." 2020. Version IV. www.equatorprinciples.com.

United Nations Development Program, and United Nations Environment. 2018. "Managing Mining for Sustainable Development: A Sourcebook."

United Nations General Assembly. 1993. Vienna Declaration and Programme of Action. UN Doc A/CONF.157/23.

. 2015. "Report of the Working Group on the Issue of Human Rights and Transnational Corporations and Other Business Enterprises." UN Doc A/70/216.

United Nations Human Rights Council. 2009. "Promotion and Protection of All Human Rights, Civil, Political, Economic, Social and Cultural Rights, Including the Right to Development: Report of the Special Rapporteur on the Rights of Indigenous Peoples, James Anaya." UN Doc A/HRC/12/34.

. 2011a. "Report of the Special Representative of the SecretaryGeneral on the Issue of Human Rights and Transnational Corporations and Other Business Enterprises, John Ruggie." UN Doc A/HRC/17/31.

. 2011b. Human Rights and Transnational Corporations and Other Business Enterprises. UN Doc A/HRC/RES/17/4.

. 2013a. "Report of the Special Rapporteur on Contemporary Forms of Racism, Racial Discrimination, Xenophobia and Related Intolerance, Mutuma Ruteere. Visit to the Plurinational State of Bolivia." UN Doc A/HRC/23/56/Add.1. 
. 2013b. "Report of the Special Rapporteur on the Rights of Indigenous Peoples, James Anaya: Extractive Industries and Indigenous Peoples." UN Doc A/HRC/24/41.

- 2014. "Elaboration of an International Legally Binding Instrument on Transnational Corporations and Other Business Enterprises with Respect to Human Rights." UN Doc A/HRC/26/L.22/Rev.1.

_. 2019. "Report of the Working Group on the Universal Periodic Review: Plurinational State of Bolivia." UN Doc A/HRC/43/7.

Wettstein, Florian. 2015. "Normativity, Ethics, and the UN Guiding Principles on Business and Human Rights: A Critical Assessment." Journal of Human Rights 14 (2): 162-82. 